\title{
読書時の心的負荷に関する基礎実験 \\ Basic Experiment on the Mental Workload of Book Reading
}

\author{
O高橋 岳大 ${ }^{1}$. 前田 倿信 ${ }^{1.2}$, 宮川 道夫 ${ }^{1}$ \\ 1. 新潟大学工学部福祉人間工学科 2. 広島大学大学院工学研究科 \\ OTakahiro Takahashi', Yoshinobu Maeda ${ }^{1,2}$ and Michio Miyakawa ${ }^{1}$ \\ 1. Department of Biocybernetics, Faculty of Engineering, Niigata University \\ 2. Graduate School of Engineering, Hiroshima University
}

\begin{abstract}
1. はじめに
総務省統計局の平成 13 年社会生活基本調查では, 60 歳以上 の高龄者の趣味・虽楽の第二位に“趣味としての読書”がある”。 本研究では，提示文字を故意に“ぼかす”(Fig. 1 参照)ことにより， 擬似的な視力低下を引き起こし, 晴眼の被験者の文字の判読時 間を計測した. その際, 前頭前野の酸素化へモグロビン鋠度の增 分 $(\Delta \mathrm{O} 2 \mathrm{Hb})^{2)}$ を同時計測した.
\end{abstract}

(a)

(b)

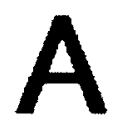

Fig. 1: (a) Ordinary character (b) Vaguely character

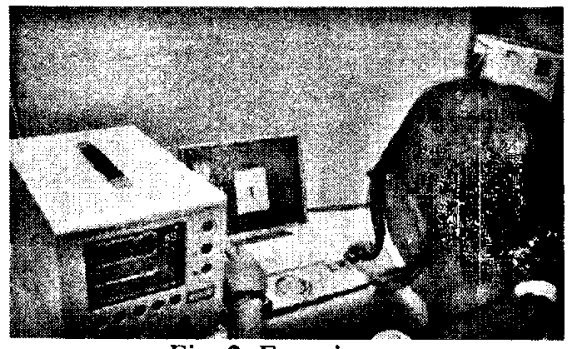

Fig. 2: Experiment

\section{2. 实换方法}

Fig. 1 に示すようなアルファベット 26 文字をランダムに提示する ソフトウェアを作成した. 被験者が単純にボタンを押す単純反応 時間, 記憶文字かどうかの選択反応時間, 単純平滑化フィルタを かけて提示文字を“ぼかした”場合の選択反応時間の3つの時間 を計測する. 以下, 単純反応時間の計測を課題 1 , 選択反応時 間の計測を課題 2, 単純平滑化フィルタをかけて文字をほかした 場合の選択反応時閒の計測を課題 3 とし, それぞれの計測の前 に 3 分間の安静時間を設けた。課題 1 では, 被験者は画面上に アルフアベットが表示されたらキーを押す動作を行う。課題 2 では， 被験者は初めに画面上に提示される 7 つのアルファベットを記憶 し，画面上に表示されるアルファベットが最初に記憶したものと同 じかを判断する．同じであれば「正」のキーを，異なっていれば 「謓」のキーを，不明の場合は「不明」のキーを押す動作を行う. 課 題 3 では, 課題 2 と同じく被験者に初めに画面上に提示される 7 つのアルファベットを記憶させ, その後, Fig. 1(b)に示すような “ぼかした”文字を提示して正誤判断をする. 実験はそれぞれの 課題で 100 回繰り返し, 最初の 10 回を除いた後半 90 回から得ら れる反応時間と正答率を求めた. 前頭前野の $\Delta \mathrm{O} 2 \mathrm{Hb}$ は, 赤外 線酸素モニタ装圆(NIRO-120, 浜松ホトニクス)を用いて実験開 始から 100 回繰り返した後まで連続に計測された. 被験者は晴眼 者 4 名 (大学生男子 2 名，女子 2 名)で Fig. 2 に示すように被験 者から $50 \mathrm{~cm}$ 離れた位置に文字を提示して実験を行った.メガネ やコンタクトレンズ使用者はそれらを使用したままで(すなわち通 常の状態で) 実験した.

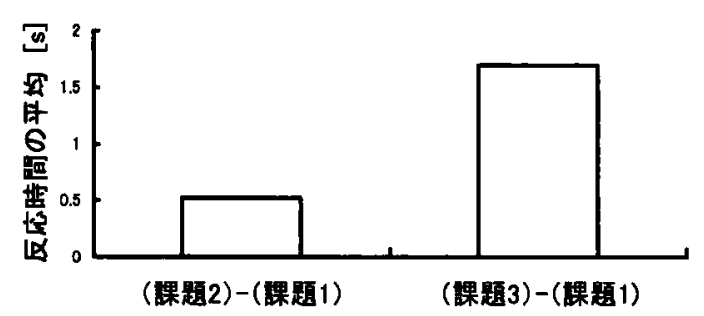

Fig.3: Response time

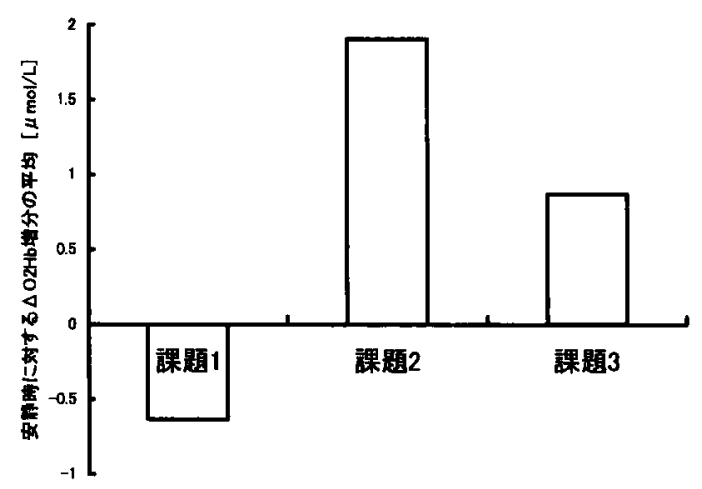

Fig.4: Increase of $\Delta \mathrm{O} 2 \mathrm{Hb}$

\section{3. 結果}

Fig. 3 に各反応時間(課題 2, 3から単純反応時間である課題 1

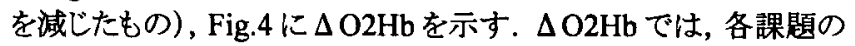
直前の安静時の平均との差を示した. 提示文字が“ほける”ことで, 反応時間は約 1 秒増加した. また, $\Delta \mathrm{O} 2 \mathrm{Hb}$ は約 $1 \mu \mathrm{mol} / \mathrm{L}$ 減少 した.ただし，単純反応時間を計測した課題 1 に対して，選択反 忘時間を計測した課題 2,3 は安静時に比して增分傾向がみられ た. 課題 2 の正答率は平均 $95 \%$, 課題 3 の正答率は平均 $91 \%$ で あった.よって，提示文字が“ぼける”と正答率は僅かに減少し た.

\section{4. まとめ}

本実験では，提示文字を“ぼかした”ときの選択反応時間の増 加量之前頭前野の酸素化へモグロビン洪度の増分を被呀者 4 名 で計測した. 今後は被験者を増やし, 統計的な有意差検定を行 う.

\section{孝文献}

1）前田義信, 宮川道夫, 視覚障害シミュレータを用いた読書行 為のワークロード評価. ヒューマンインタフェースシンポジウム 2007;9 月予定.

2）星詳子, 光脳機能イメージング. 精神研 NEWS 2006; no. $320: 1-3$ 